\title{
The Object and Its Significance in Crimes of Looting Other's Property by Using Computer Tools
}

\section{Kh.R. Ochilov}

$\mathrm{PhD}$, Associate Professor, Head of the Department of Criminal law, Criminology and Fight against Corruption of Tashkent State University of Law

\section{ABSTRACT}

It should be noted that some types of plundering can damage not only property, but also other social relations protected by criminal law, that is, such crimes affect several social relations at once. In criminal law, crimes of this type are called crimes of a complex nature if the damage is caused to more than one object as a result of the commission of a socially dangerous act.

The crime of looting other people's property by means of computers is also a crime of a complex nature, ie not only property relations, but also social relations in the field of information technology, and in some cases social relations in the field of public administration. will also be damaged.

As a rule, in complex crimes, the object is qualified depending on the main direct object, if the objects affected are two or more social relations protected by criminal law.

In robberies of other people's property using computer tools in most cases, the object of the crime is not in the direct possession of the victim, ie non-cash money is usually kept in a special institution (bank) or device (plastic card) where the money is stored and authorized to carry out certain operations.

Generally, the property of another is defined as property that is not in the possession or legal possession of the offender. However, such an interpretation does not apply to the crime of misappropriation or robbery of another's property by means of computers, as the subject of the crime uses special powers in relation to the subject of the robbery, ie abuses the trust of the owner and the perpetrator robs him.

The fact that special powers in relation to property are the main special feature of the crime of embezzlement or plundering is determined by the disposition of the property in the disposition of the criminal law.

However, non-cash money in a specific account entrusted or pledged to the defendant or at the disposal of the defendant shall not constitute the subject of misappropriation or misappropriation by computer means.

In this case, the actions of the offender are qualified by the relevant articles of the Special Part of the Criminal Code, which provide for liability for crimes against justice, and are not qualified as a set of crimes under the articles of liability for robbery.

Keywords: plundering, property, computer facilities, thieving, embezzlement, computer tools, prevention, fraudulent, computer fraud, looting.

Article Received: 10 August 2020, Revised: 25 October 2020, Accepted: 18 November 2020

\section{Introduction}

Global cybercrime is becoming increasingly trouble by taking more than 200,000 casualties, causing nearly 500 billion property damage to individuals and businesses as a result of these crimes, and by Juniper Research in 2016, the loss from computer fraud by 2019 is about 2.1 trillion US dollars, the crime rates by $10-15 \%$ each 
month indicate that the fight against these crimes is internationally recognized. The sharp development of social relationships has resulted in the expansion of forms and forms of crime related to the plundering of others' property. In particular, modernization of computer equipment, in turn, contributes to the expansion of its capabilities and the increase in the number of offenses, in particular the usage of computers facilities, and the increase of their social danger.

In the Global Information and Computerization Age in the world, along with the most prominent discoveries in our life, it is necessary to determine the criminal-legal and criminological aspects of embezzlement of one's belongings by the use of computer tools by threatening information security, and to counterbalance bank plastic cards, which are non-cash payments. defining criminal responsibility for conducting fake bank plastic cards, analyzing the situation and dynamics of these crimes, the causes and conditions of the disease, the study of the criminality and the elaboration of recommendations for their prevention.

As a result of the judicial reforms in Uzbekistan during the years of independence, certain progress has been achieved in ensuring the compliance of society members with the law, raising the responsibility of law enforcement agencies, protecting citizens against external threats and harassment and combating crime. As the second priority point in the priority areas of the law-making and further reform of the judicial-legal system of the Strategy of activities for 2017-2019 approved by the Decree of the President of the Republic of Uzbekistan dated February 7, 2017, PF-4947, is the priority task of «strengthening the effectiveness of coordinating the activities of crime prevention and combating offenses» as a priority for the continuation of reforms.

Using a computer technologies in our country to spoil others' property or embezzlements (in accordance with «g» part of 3 chart of 167 article), by $10.5 \%$ in 2010 2016; Theft (robbery) by using these devices (in accordance with «V» part of the second chart of 168 article) by $20.6 \%$, unauthorized entering the computer system and made theft (in accordance with «b» part of the third chart of 169 article) by $16 \%$ increased. The majority of these cases are unchangeable, so that it is impossible to restore the violated property rights of individuals due to the large number of damages inflicted on legal entities and individuals. There is a need for further improvement of criminal responsibility for these crimes in the course of the ongoing judicial and legal reforms.

This dissertation research will serve to a certain extent for the fulfillment of tasks mentioned in Criminal code of the Republic of Uzbekistan (1994) and laws of the Republic of Uzbekistan «On prevention of offenses» (2014), «On internal affair bodies» (2016), Presidential Decree «On measures to further improve the system of crime prevention and combating crime» (2017), the Decree of the President of the Republic of Uzbekistan on the «On the Strategy for Further Development of the Republic of Uzbekistan» (2017) and other legislative acts.

\section{Methodology}

Historical, structural, comparative legal, logical, exact sociological, complex research of scientific sources, induction and deduction, and statistical data analysis were used in the research.

\section{Discussion and Results}

A detailed analysis of its objective features in the study of the composition of a particular crime - allows to draw clear and accurate conclusions about them. In general, the objective signs of a crime are the features of the object and the objective side of a particular crime. The act deserving a criminal punishment - the analysis of the content of the crime begins with the identification of the object of the crime. "Object" is derived from the Latin word "objicio", which means "against" [1; p. 130], and the object of the crime represents the social relations associated with values, wealth, protected by criminal law in itself $[2 ; 356-b$.].

In recent publications [3; p. 74] the object of the crime is divided into four types: 
general, related, special and direct objects. According to it, the common object of crimes is social relations, which are protected by the sum of all articles of criminal law. According to R. Kabulov, the general object of the theft crimes is the social relations protected by criminal law and listed in Article 2 of the Criminal Code [4; p. 234]. E.O. Alaukhanov writes that "although the crime of robbery encroaches on social relations related to property, they are closely related to other groups of social relations, all of which together form a common object of the crime of robbery" [5; p. 12. ].

The looting of other people's property is literally directed against the economic foundations of the state. After all, as defined in the Constitution of the Republic of Uzbekistan, the basis of the economy is various forms of property. As a result of the crime of robbery, social relations related to property are damaged.

A related object of the crimes in Part III of the Special Part of the Criminal Code is social relations in the field of economics [6; $p$. 38]. V. Didenko argues that, these crimes occur as a result of encroachment on property relations in the economic sphere, the object of criminal aggression in this area can be combined on the basis of a single concept of "economy" [7, p. 3]. B. Nikiforov also noted that "the specificity of social relations is determined by, first of all, the commonality of social interests that make up the content of social relations; secondly, the closeness and similarity of the participants of social relations" $[8 ;$ p. 155]. At the same time, the main feature of a related object is that it unites a group of social relations that are close to each other.

A common feature for the crimes of looting the property of others is the special object of these crimes, i.e., the social relations associated with the property [9; p. 358].

Experts consider property as a special object of looting as a thing, property rights, property interests, economic category, legal category or generally reject property as an object of crime. In our opinion, the special object of the crime of looting in Chapter 10 of the Special part of the Criminal code, which contains the legal norms established for liability for looting of another's property by means of computers, is the property and property rights of others. According to E.O. Alaukhanov, "the object of aggression in the looting of property, that is, the social value that is violated in any case and always, is the property relations established by the state. In short, the main and direct object of the crime of theft crimes is property relations " $[15 ; \mathrm{p}$. 10]. In our opinion, it would be expedient if this definition, given to the direct object of theft crimes, was applied to its special object. The reason is that it is advisable to determine the direct object of the crime of theft crimes, including the looting of another's property using computer means, based on the forms of robbery (misappropriation, embezzlement, fraud and theft).

It should be noted that certain types of theft crimes can damage not only property, but also other social relations protected by criminal law, that is, such crimes affect several social relations at once. In criminal law, this type of crime is called a crime of a complex nature if the damage is caused to more than one object as a result of the commission of a socially dangerous act. The crime of looting other's property by means of computers is also a crime of a complex nature, i.e by committing these types of crimes not only property relations, but also social relations in the field of information technology, and in some cases social relations in the field of public administration will also be damaged. As a rule, in complex crimes, the object is qualified depending on the main direct object, if the objects affected are two or more social relations protected by criminal law.

In criminal law, "the main direct object is defined as social relations protected by criminal law that are socially dangerous aggression directly targeted. That is, without this object, there would be no criminal structure" $[16$, p. 20]. It is the looting of other people's property using computer tools, as a form of theft, that primarily encroaches on property relations. In this case, the intent of the perpetrator is directed to the property or 
property rights of other persons. In the process of aggression against this object, a second social relationship, which is simultaneously aggressed with it, forms an additional direct object.

An additional direct object is another social relationship that is protected by criminal law when the main direct object is attacked. An additional direct object in the looting of other people's property by computer means is often social relations in the field of information technology.

Based on the above, it can be concluded that the general object of the crime of looting the property of others using computer means is the general social relations protected by the criminal law; related object - a set of social relations in the field of economy; the special object consists of property relations.

The direct object of this crime, as noted above, should be identified in relation to each form of these theft crimes.

In particular, the direct main object of misappropriation and embezzlement of other's property by using computer means is property relations arising between the owner and the persons who have the right to own, use and dispose of his property; an additional direct object is social relations related to the security of computer information, as well as the order of using automated data processing systems; while misappropriation of official position, social relations that ensure the normal functioning of public authorities, administration and local self-government are also an additional direct object of the crime. Some experts argue that fraudulent looting of another's property using computer tools may not, in some cases, encroach on an additional direct object in some cases, unlike other types of computer looting.

After all, an offender can rob a victim by deceiving or abusing his trust without affecting the database stored in the computer system (for example, offering to send a certain amount of money to the specified address to win by giving false information about winning the lottery via the Internet) to do) is also referred to as a manifestation of computer fraud [17; p. 122].

Without agreeing with this view, we would like to point out that the main feature of all computer looting is that in all these types of crimes, two objects which protected by criminal law are invaded, i.e. there are an additional direct object, at the same time the main object.

Hence, the direct main object of fraudulent looting of other's property by using means of computers is the social relations connected with property and property rights; an additional direct object is the relations in information exchange system, as well as in the field of information security.

The direct main object of looting of other's property by using computer means is the relations related to property and property rights; the additional direct object is social relations in the field of information security and inviolability, ensuring the normal functioning of the computer system or network.

The literature suggests that it would be appropriate to recognize social relations in the field of information technology as the main direct object in the looting of other people's property using computer tools and to classify the act as a crime in the field of information technology [18; p. 153].

In our opinion, this idea contradicts the general rules and requirements of criminal law. Indeed, the question of which article of the Special Part of the Criminal Code qualifies a two-object act as committed depends on the social relations (the main direct object) to which the offender's criminal aggression is directed. In the case of looting of other's property using computer tools, the intention of the perpetrator is primarily aimed at looting other's property, which damages the information system during the seizure of property.

In short, the main direct object of the crime of looting others property by using computer means is a property relationship characterized by specific features that apply to each form of computer looting; an additional 
direct object is social relations in the field of information technology.

At the same time, let us clarify the subject matter of this crime. As a rule, the subject matter of a crime is a material thing that exists in the objective life in which the crime is committed because of it or in connection with it [19; p. 160].

The subject of the crime of theft crimes, for which liability is provided for in Chapter 10 of the Criminal Code, is one's property. In the legal literature, property is understood to mean a thing, money and securities, other property or property rights (Article 128 Civil Code), and here they are used in two senses: narrow (property as thing) and broad (property as a whole and property rights). There should be no difference in the definitions given to property in criminal and civil law, as the concept in civil law is convenient and acceptable.

Therefore, we agree that the notion of property in the narrow sense in criminal law as the subject of crimes against property is incorrect [20; 41-b.].

According to E. Tenchev, "the subject of looting of other people's property is the property of others, as well as the right to property, i.e property rights and property services (actions)" [21; p. 199]. Agreeing to this, it should be noted that the subject of looting other people's property by using computer tools are property and property rights.

Some researchers believe that since the subject of the crimes of looting other people's property is one's property, only:

1) a sign of materiality - having a certain physical form;

2) economic sign - having an objective economic value;

3) social sign - absorbed human labor;

4) not excluded from civil circulation;

5) socio-economic sign - the presence of citizens, government agencies, enterprises, institutions, organizations or public associations at the time of looting;
6) legal character - only property that has such characteristics as the property of another may be the subject of the crime of looting of other's property [22; p. 12].

Yu.I. Lyapunov "from the economic point of view, property means property with a certain value. Property that has lost its material value for the state, legal entities and individuals for one reason or another cannot be the subject of the crime of looting other's property". The social sign of property is property that has been transformed from a pure state of nature into a form of property due to the incorporation of human labor in its creation " $[23 ; 33]$. Although the abovementioned features are also specific to the subject of looting of other's property by using means of computers, it should not be overlooked that the subject of this crime has some exceptions. In particular, materialism, that is, the fact that the object of looting has a certain physical form, can not be applied in all cases to the crime of looting other's property by using computer tools. This is due to the fact that in these crimes, mainly non-cash funds in the form of information are looted. Today, the issue of non-cash money being the subject of theft crimes is controversial. In particular, P.S.Yani, M.V.Frolov, G.V.Verina, O.I.Godunov emphasize that non-cash money is not the subject of looting[24; 25-p., 25; Pp. 56,$26 ;$ p. 161, 27; p. 93]. They believe that non-cash money, by its legal nature, is not a tangible object in civil transactions, but its content is a property obligation that constitutes the return or transfer of a certain monetary value by the bank to the client (account holder). Ya.S.Vasileva, A.V.Khabarov, L.Efimova, O.Oleykin, A.V.Shulga, on the contrary, consider noncash money as a form of money existence and include it in the subject of looting [28; p. 20, 29; 97-b., 30; 12-b., 31; 56-b.]. In our opinion, non-cash money is the subject of looting. Because, in accordance with Article 16 of the Law of the Republic of Uzbekistan "On electronic payments" of December 16, 2005, an electronic payment document is equivalent to a monetary document and has the same legal force. This is especially evident in the form of non-cash money when 
looting other people's property using computer tools, which is a form of looting. That is, it directly encroaches on tangible (electronic, informational) property, rather than other theft crimes. It is stored not anywhere, in any place, but in the memory of fixed and portable special devices and equipment, and in institutions specialized to perform this activity. In particular, the above law stipulates that electronic payment documents are stored on electronic media (Article 15). The economic sign is also characterized by specific features in looting of other people's property by using computer tools. That is, programs and databases for computers that have economic value and are not disclosed; inventions, utility models, industrial designs; selection achievements; undisclosed information, including intellectual property, such as production secrets, know-how (Article 1031 CC), may also be the subject of this crime. The reason is that if the listed intellectual property is seized for malicious purposes, the act does not constitute a crime of infringement of copyright or invention under Article 149 of the CC, because the actions to be taken in the analysis of the disposition of Article 149 of the CC not intended. Nor can we agree with the idea of denying another characteristic inherent in the subject of looting - the absorption of human labor (the social sign) [32; p. 13]. In addition to the above, the subject of looting other people's property by using computer tools is required to be only property that has not been removed from civil circulation. If the property withdrawn from civil circulation is looted using computer means, this act does not constitute a theft crime, because this property is not recognized as the subject of looting. In this case, these properties constitute the subject of the offenses provided for in Chapters 17 and 19 of the Special Part of the Criminal Code, the act is qualified as a total of offenses under these articles and articles in the chapter on crimes in the field of information technology. Socio-economic sign, which is another feature of the object of looting, has a special feature in the looting of other people's property using computer tools. This usually means that at the time of the robbery, the property that is the subject of the crime should be in the direct possession of citizens, government agencies, enterprises, institutions, organizations or public associations. In the case of computer looting, in most cases, the object of the crime is not in the direct possession of the victim, ie non-cash money is usually stored in a special institution (bank) or device (plastic card) authorized to carry out certain operations. Generally, another's property is defined as property that is not in the possession or legal possession of the offender.

However, such an interpretation does not apply to the crime of misappropriation and embezzlement another's property by means of computers, as the subject of the crime uses special powers here, ie abuses the trust of the owner and the perpetrator robs him. The fact that special powers in relation to property are the main special feature of the crime of misappropriation and embezzlement is determined by the disposition of the criminal law. However, non-cash money in a specific account entrusted or pledged to the defendant or at the disposal of the defendant shall not constitute the subject of misappropriation and embezzlement by using computer means. In this case, the actions of the offender are qualified by the relevant articles of the Special Part of the Criminal Code, which provide for liability for crimes against justice, and are not qualified as a set of crimes under the articles of liability for theft crimes. It is expedient to distinguish the following special features of non-cash money in the form of computer information accepted as a subject of crime of looting other's property by means of computers: 1) computer information as a subject of crime is personal property in electronic form; 2) information that has been subjected to criminal aggression - as a subject of the crime of robbery does not have a sign of materiality (physical form); 3 ) computer information affected by the offender is protected by a number of other laws ("On informatization", "On legal protection of computer programs and databases", "On telecommunications", "On electronic payments", etc.).; 4) this information is stored on information carriers (plastic cards), 
computers, as well as computer systems or networks.

In this case, it should be noted that a special device (plastic card) for storing noncash money, although very small in size, can store an unlimited amount of money and is the most appropriate measure in the implementation of monetary policy in the state. As mentioned above, the plastic card has both advantages and disadvantages, and today in developed countries, the use of computer tools called "plastic crime" is the looting of other people's property (theft of bank plastic card numbers - "pin code" or plastic card counterfeiting) is very popular and a separate article provides for liability in the CCs of these countries (for example: Article 177 of the CC of the PRC, Article 243 of the CC of the Republic of Bulgaria) [33., 34]. This is due to the fact that in the life of society, plastic cards, which are considered an electronic means of payment in the relationship with the account, are very widely used.

Today, a number of normative and legal acts have been adopted in our country to ensure the implementation of settlements with plastic cards [35]. A plastic card is a personissued payment instrument issued by a bank, which certifies the availability of funds in the account of the cardholder in the relevant bank and reflects the right to purchase goods, works and services without paying in cash. But today in our Uzbekistan, too, there are many cases of looting of property using bank plastic cards. As an example, we can cite the following criminal case. The specialist of the 2nd category on plastic cards of the money circulation department of the Qibray district branch of Ipotekabank of Tashkent region $\mathrm{R}$ using his official powers to transfer a large amount of money (more than 401 million sums)from the savings account "Liabilities of individuals on plastic cards" to illegally issued and counterfeit plastic cards using computer means and then looted the money. In this case, the court found the act in addition to the qualification in the indictment under Article 167 of the Criminal Code, part 3 "a" and "g", Article 205 part 2 "a" "b", Article
209 part 2 "a" "b" and qualified under Articles $278^{1}, 278^{2}$ and $278^{4}$ of the Criminal Code as a set of crimes [36]. In this case, the fact that the defendant had prepared or forged bank plastic cards had no effect on the qualification of his actions. Because the current Criminal Code does not provide for liability for forgery of bank plastic cards, and in our opinion, it is wrong to further qualify the actions of the perpetrator under Articles $278^{1}, 278^{2}$ and $278^{4}$ of the Criminal Code. Because the actions in Articles $278^{1}, 278^{2}$ and $278^{4}$ of the Criminal Code, part 3 of Article 167 of the Criminal Code is manifested as a method of committing a crime provided for in paragraph "g" and is fully covered by this article itself and does not require additional qualification with individual articles.

Based on the above opinions and comments and the experience of developed countries, we consider it appropriate to establish liability in Article 176 of the current CC Chapter XII for the production and counterfeiting of credit cards and to state its name and the disposition of Part 1 in the following wording:

"Article 176. Production and transfer of counterfeit money, excise stamps, securities or plastic cardsCreation or transfer of counterfeit banknotes (banknotes), metal coins, excise stamps, as well as securities or foreign currency or foreign currency securities or plastic cards for the purpose of transfer.

Based on the above proposal, we note that from the moment of preparation of the counterfeit bank plastic card for the purpose of transfer of guilty, his act is recognized as a completed crime. If the offender's actions show signs of another crime (e.g., forgery of documents, abuse of office), his actions are qualified as a set of crimes.

If the perpetrator has prepared a fake bank plastic card for the purpose of looting another's property, his actions must be qualified as a set of crimes under the articles of the Special Part of the Criminal Code, which provides for preparation for robbery and responsibility for making a fake bank plastic card. This situation would have helped 
to prevent early counterfeiting of bank plastic cards by private entities (bank employees), which are common in practice.

Similarly, in developed countries today, independent cryptocurrencies (digital virtual money) (bitcoin, litcoin), which are not subject to the laws of any country and the banking system in the form of computer information, are coming into consumption and accepted by some countries (Japan) as legal tender. The issue of organizing the subject of looting the property of others using these cryptocurrencies by computer means is somewhat controversial. While these cryptocurrencies are in the form of computer information, they are not considered the legitimate currency wealth of any state. From this point of view, in our opinion, these cryptocurrencies cannot be accepted as the subject of robbery, and the looting of these cryptocurrencies does not entail criminal liability under the criminal law of the Republic of Uzbekistan. This is due to the fact that cryptocurrencies are not recognized as a means of payment in any normative document in force in the Republic of Uzbekistan.

Based on the above considerations, the subject of looting of another's property using computer tools can be defined as follows: property in the form of tangible (with a material mark) or computer information (noncash property). Based on this definition, it would be expedient to give a different definition to the concept of the subject of the crime in the theory of criminal law in general. The reason is that the concept of the subject of crime is considered in all literature as material things that exist in objective life, ideas, views, results of human thinking, and information of economic value can not be the subject of crime. But this idea is a bit misleading today because the perpetrator affects a person's property rights and commits a crime by encroaching on the intangible (in the form of information) non-cash funds in the victim's bank account.

Based on these views and comments, we consider it appropriate to define the concept of the subject of the crime as follows. The object of the crime is the material or intangible worldly goods that are directly damaged as a result of socially dangerous aggression. In this regard, in the case of looting of another's property using a computer, the subject of the crime must be distinguished from the means and weapon of the crime. As noted above, the subject of a crime in the robbery of another's property by means of a computer is the property that has been invaded as a result of the commission of this socially dangerous act.

\section{Conclusion}

As a result of the research on «liability for embezzlement of one's belongings by the use of computer tools», the following theoretical and practical conclusions were reached:

1. Responsibility for the use of computer facilities by the expertise of world experience: 1) States where legal norms for property crimes are widely practiced and those which are subject to computer analogies according to law analogy; 2) States that are subject to liability for crimes against property as a condition of aggravating or alleviating computer looting; 3) the states in which special laws are binding for crimes against property; 4) For spoofing of computers is divided into the states which are subject to liability in a separate article of the criminal law.

2. Embezzlement of the one's property with the use of computer technologies. Property relationships, which are characterized by specific features, which are directly related to any form of computer embezzlement, which are directly addressed to the subject of robbery; and the direct accessory object is social relations in the field of information technology.

3. Embezzlement of the one's property with the use of computer technologies. The subject of inquiry shall be property of material or computer information (non-cash money, intellectual property) that has a definite economic value, which is not a guilty party, or a lawful possession of the defendant, without the right to dispose of it. 
4. The following specific peculiarities of non-cash money in the form of computer information have been identified as the subject of spoiling the property of others:

1) Computer information as the subject of the offense is personal property in electronic form;

2) Information that has been subjected to criminal offenses - does not have an ascetic (material) designation as a subject of extortion;

3 ) in the form of computer information in the data carrier (plastic card), computer system or network.

5. Use of computer facilities means to seize, detain, or inflict property damage to the proprietor, without the implied warranty of any kind, for the purpose of preventing the return of the property (non-cash funds) in the form of computer information that is entrusted to or It is understood that the intentional modification of the computer system, which determines the fate of this property, is in the interest of the enjoyment of this property by its own interests.

6. The use of a computer to seize a person's property by means of a confiscation of property, without prejudice to the rights of the proprietor, in order to prevent the return of his property (non-cash assets) in the form of computer information, through the modification of the information on the computer system to determine the fate of that property in order to cause property damage, the alienation of such property in favor of third parties or it is understood.

When plundering of property by means of computer technologies is carried out by means of embezzlement or it is transferred from the moment of receipt (acquisition) of the property (non-cash) entrusted or at the disposal of the guilty to another account of non-cash money is considered to have expired, that is, from the moment of the alienation.

7. Using fraudulent possession of a person's property by means of a computer, by means of modification of the information stored on the computer, or by misuse of confidence, intentionally, mercilessly, to free property of the other person by property damage. Computer fraud is a crime that has been committed since the moment when the guilty person was able to dispose of the real estate.

8. To consider as a computer fraud committed by deception:

1) Not transferring false information to a victim through the computer (eg sending a certain amount to a winner or winning a prank, noting that the winner in the lottery was victimized) did not constitute computer fraud;

2) the computer should facilitate the commission of a crime as a means of committing fraud, that is, through the modification (modification) of information stored in the computer information system;

$3)$ the modification of computer information has proven that simultaneous existence of the subject must be present, as if the owner or the person entrusted with the property voluntarily gives it to a fraudster.

9. Intentional, non-violent, free use of the property by the use of a PC, by stealing someone else's property, illegally using the computer information system, and modifying it in the property.

The offense is considered to have been completed from the moment the non-cash money has been credited to the account of the perpetrator or another person.

10. Spoofing of the property of others by means of computer facilities, without the illegal (unauthorized) attack on the computer information system, the return of the property by modification of the information, the property damage to the owner, is the occurrence of

11. In connection with the complementation of the new Article of the Criminal Code of the Republic of Uzbekistan, article 167, part 3, «g» of the Criminal Code, «committed by using computer facilities»; Article 168, part 2, «V» of the "committed by using computer facilities", article 169, 
paragraph $3 \ll b »$, "unauthorized access to the computer system" should be excluded from the Criminal Code;

12. It is recommended that using a computer to differentiate criminal responsibility for illegal possession of firearms, ammunition, explosives or explosive devices, for this purpose it is proposed to supplement Article 247 part 2 of the Criminal Code with «e» below: facilities».

«E) committed by using computer

It is considered more proper to supplement illegal acquisition of forceful or toxic substances (Article 251) or inclusion into circulation (Article 139), infringement of the constitutional system of the Republic of Uzbekistan (Article 159), disclosure of state secrets (Article 162) (Article 251 ${ }^{1}$ ), illegal possession of radioactive materials (Article 252) with aforementioned norms;

\section{References}

[1] Уголовное право. Общая часть: Учебник для вузов / Под ред. И.Я.Козаченко, З.А.Незнамова. M.: HOPMA, 2001 - C.130.

[2] Большая юридическая энциклопедия. Самое полное современная издание. - М.: Эксмо, 2008. - C. 356.

[3] Коржанский Н.И. Объект преступления и предмет уголовноправовой охраны. - М., 1980. - С. 74.

[4] Кабулов Р. Уголовно-правовые меры борьбы с хищениями: теория и практика: Дисс. ...докт. юрид. Наук. - Ташкент, 1997. - С. 135, 137;

[5] Алауханов Е.О. Квалификация хищения совершенных по подложных документам / Отв. ред. проф. Г.А.Ахмедов. - Алматы Ташкент: Адолат, 1994. - С.12.

[6] Мирзаев У. Ўзлаштириш ёки растрата йўли билан талон-торож қилганлик учун жавобгарлик муаммолари. Юрид. фан. ном. ... дисс. - Тошкент, 2009. - Б. 38.

[7] Диденко В.П. Квалификация хищений государственного или общественного имущества путем присвоения, растраты или злоупотребления служебным положением. - Киев, 1992. - С.3.

[8] Никифоров Б.С. Объект преступлений. - М., 1960. - С.155.

[9] Уголовное право. Учебное пособие / Под ред. Проф. Л.Д. Гаухмана и проф. C.B. Максимова.- М.: Элит, 2007. - 358 c.

[10]Прохоров В.С. Преступление и ответственность. - Л.: ЛГУ, 1984. C. 44-56.

[11]Российское уголовное право. Общая часть. Учебник / Под ред. В.Н.Кудрявцева, А.В.Наумова. М., 1996. - C.84, 91-92;

[12]Уголовное право. Особенная часть: Учебник / Под ред. проф. Л.Д.Гаухмана и проф. С.В.Максимова. - М.: Эксмо, 2005. - C. 141-194.

[13]Незнамова 3.А. // в кн.: Уголовное право. Особенная часть: Учебник / Отв. ред. И.Я.Козаченко, Г.П.Новоселов. - М.: Норма, 2008. - C. 209.

[14]Клепицкий И.А. Собственность и имущества в уголовном праве // Государство и право. - Москва, 1997. - №5. - C. 74-83.

[15]Алауханов E.O. Криминологические предупреждения проблемы насильственных преступлений. Автореф. дисс. ... докт. юрид. наук. - Алматы, 2004. - С.10.

[16]Новоселов Г.П. Учение об объекте преступления. Методологические аспекты. - М.: HOPMA, 2001. - C. 20. 
[17]Абдуқодиров Ш.Ё., Мирзаев У.М. Мулкни талон-торож қилганлик учун жиноий жавобгарлик. Тошкент. ТДЮИ, 2009. - Б.122, 158 ;

[18]Абдуқодиров Ш.Ё., Мирзаев У.М. Мулкни талон-торож қилганлик учун жиноий жавобгарлик. Тошкент. ТДЮИ, 2009. - Б.158.;

[19]Усмоналиев М. Жиноят хуқуқи. Умумий қисм. Дарслик.-Тошкент: Янги аср авлоди, 2005. - Б. 160.

[20]Мирзаев У. Ўзлаштириш ёки растрата йўли билан талон-торож қилганлик учун жавобгарлик муаммолари. Юрид. фан. ном. ... дисс. - Тошкент, 2009. - Б. 53.

[21]Уголовное право России. Часть особенная. Учебник. - М.: Волтерс Клувер, 2005. - С. 199.

[22]Мирзаев У. Ўзлаштириш ёки растрата йўли билан талон-торож қилганлик учун жавобгарлик муаммолари. Юрид. фан. ном. ... дисс. - Тошкент, 2009. - Б. 53.

[23]Люпунов Ю.И. Драгоценные металлы как предмет преступлений // Соц. законность. 1981. - №7. - С. 33.

[24]Верина Г.Ф. Дифференциация уголовной ответстевенности за преступления против собственности: проблемы теории и практики: Автореф. дис. ...докт. юрид. наук. - Саратов. - 2003. -C. 25 ;

[25]Годунов О.И. Присвоение и растрата как формы хищение (уголовно правовой и криминологический анализ): Дис. ...канд. юрид. наук. - Иванова, 2005. - С. 56.

[26] Фролов М.В. Имущество как предмет хищения: единство и дифференциация гражданскоправового и уголовно-правового моментов понятия: Дис. ...канд. юрид. наук. - Екатеринбург, 2002. - C. 184.

[27]Яни П.С. Экономические и служебные преступления. - М.: Бизнес школа Интел-Синтез, 1997. - C. 93.

[28]Васильева Я.С. Уголовная ответственность за деяния, совершенные в сфере кредитных отношений: Автореф. дис. ...канд. юрид. наук. - Екатеринбург, 2000. - C. 20 ;

[29]Ефимова Л. Правовые аспекты безналичных денег // Закон. Москва, 1997. - № 1. - С. 97;

[30]Хабаров А.В. Преступление против собственности; влияние гражданско-правового регулирования: Автореф. дис. ... канд. юрид. наук. - Тьюмен, 1999. - C. 12 ;

[31]Шульга А.В. Присвоение или растрата в условиях становления рыночных отношений / под ред. Р.Р. Галиакбарова. - Краснодар: Кубанский гос. агр. ун-т, 2004. C.56.

[32]Хабаров A.В. Преступление против собственности; влияние гражданско-правового

регулирования: Автореф. дис. ... канд. юрид. наук. - Тьюмен, 1999. - C. 13 ;

[33]Уголовный Кодекс Китайской Народной Республики. СанктПетрбург. Юридический центр Пресс.2001. под редакцией д.ю.н.проф., А.И.Коробеева.

[34]Уголовный Кодекс Республики Болгария. Санкт-Петрбург. Юридический центр Пресс.2001. под редакцией к.ю.н., А.И.Лукашова.

[35] $]^{1}$ Central Bank of the Republic of Uzbekistan. 12.01. 2002., №1 / 4 (60). Regulations on cashless accounts in the Republic of Uzbekistan; Resolution of the 
Cabinet of Ministers of the Republic of Uzbekistan dated 24.09.2004 № Resolution No. 445 on measures to further develop the accounting system on the basis of plastic cards; President of the Republic of Uzbekistan 03.08.2006 Resolution № 433 on additional measures for further development of the accounting system on the basis of plastic cards.

[36]From the archives of the Regional criminal court of Tashkent, criminal case No. 61-266 / 09, 2015. 